\title{
Enforced Alienation and Unheard Female Voice under Patriarchy in Atwood's Bodily Harm
}

\author{
Dr. Suchitra Misra
}

\begin{abstract}
Margaret Atwood is a Prolific and an outstanding feminist Canadian writer who has been shortlisted for the Booker Prize five times, winning once. She is among the best writers in Canada and has achieved a celebrity status and become a cultural icon.

In her fifth novel Bodily Harm, Atwood exposes societal decay and violence against women under patriarchy. It also includes violent pornography, rape, abuse and murder. This violence is discussed on the several levels: Private, Public and Universal. This Physical and mental abuse brings about enforced alienation and unheard female voices in male dominated society. A young journalist Rennie Wilford, the protagonist, seems to be a lonely woman, aloof from her body, background and family. Atwood explores the motif of illness for the first time, the protagonist is suffering from a terrible disease viz. breast cancer that affects a great number of women. The breast cancer is depicted as a national and universal disease and also co-related with violence. In fact Bodily Harm is a dark character study of a woman who feels shattered and unable to relate whatever is happening around her.
\end{abstract}

Keywords-Enforced, Alienation, Unheard, Patriarchy, Margaret Atwood, Bodily Harm.

\section{INTRODUCTION}

$\mathrm{M}$ ARGARET Atwood --- One of Canada's best, popular and is among the most successful writers and a social activist who received international repute after winning Booker Prize. The quest for identity and feminist voice of Atwood is clearly audible in her novels like The Edible women, Surfacing, Lady Oracle, Bodily Harm and many more. These novels exhibit the strength and proactive nature of women as they struggle on gender issues. They are compelled to bear the social system which categorizes and labels them as inferior or superior, pious or impious.

In her fifth novel Bodily Harm [1981], Atwood aims after women's liberation movement. She exposes societal decay, the patriarchal structures of dominion and power, female search for identity and Canada's similar quest for national identity. The spirit of cultural nationalism assisted by federal support and aid has greatly facilitated her writings. She mentioned violent pornography, rape, abuse and murder. The violence is discussed on the various levels; private, public and universal. This physical, sexual and mental abuse brings about enforced alienation and suffocated female voices in male dominated society.

The protagonist, Rennie Wilford is a Canadian freelance

Incharge, Dept of English, M.M.V. (P.G.) College, Kidwai Nagar, Kanpur (U.P) India e-mail -mishrasuchitra1974@gmail.com). journalist who seems to be a lonely woman but uses 'pen' as a weapon to write her travelogues regarding violence and victimization of women. She paves her way towards the goal of specialization through a life of tension and conflict and reveals the wickedness of men and their brutality done to female body. She is brought up in an unhealthy and conservative environment by her grandparents in a small town, Griswold. Her childhood is suppressed by her grandmother's conservative approach of do's and don'ts. She is never allowed to think and feel independently and she says "as a child I learned three things well; how to be quiet, what not to say, and how to look at things without touching them. When I think of that house I think of objects and silence. The silence was almost visible." [54]. Her father was an irresponsible man who has left his family due to his extra-marital affair in Toronto. Her mother has sacrificed everything- husband, home and family to look after her aged parents. Rennie hates the compromising spirit of her mother and chooses to break away from such an environment: I didn't want to be trapped, like my mother. Although I admired her-everyone was telling me how admirable she was, she was practically a saint- I didn't want to be like her in any way.[58]

Rennie feels suffocated in such a polluted environment as she leaves the place in order to lead a life of freedom where there would be no shackles to bind, such that would kill her own individuality and identity. She begins her adult life in Toronto as a versatile writer and comes in contact with Jake and falls in love with him. Rennie takes quite a long time to realize that Jake is a sexual exploiter. For him love is a crude game intended to hurt women. As Rennie says: "Jake liked to pin her hands down, he liked to hold her so she couldn't move. He liked that; He liked thinking of sex as something he could win at. Sometimes he did really hurt her, once he put his arm across her throat and she really did stop breathing." [207]

Later on, Rennie is diagnosed as having breast cancer, undergoes a partial surgery and overcomes the disease. She engages in an abortive love affair with her surgeon Dr. Daniel. "He wasn't very far away. She fell in Love with him because he was the first thing she saw after her life had been saved". [32] She allows him to touch her with his life giving hands. Daniel violates the professional ethics by taking advantage of her in her emotional state. Ultimately, Rennie realizes that Daniel too is a victimizer who exploits women in the guise of medicine and surgery. She says: "May I am not the only one there's a whole line up of them, dozens and dozens of women, each with a bite taken of women, each with a bite taken out of them, one breast or the other".[142]

In the meantime her relationship with Jake also comes to an 
end. Later, Rennie comes to know that a faceless stranger has entered forcefully into her house when she was out. The stranger has left a length of rope coiled on the bed. "The piece of rope which was evidence... it was someone's twisted idea of love. Every time she went into her bedroom she could see it. Coiled in the bed, even though it was no longer there".[41] It reveals the decayed social conditions which directly lead to frustration, victimization as well as physical assaults on women. The threatening behavior of the stranger at Rennie's home illustrates what could happen if women were to stop struggling for survival and do not accept victimization.

After the incident of coiled rope she began to have nightmares and would often wake up sweating. She thought it was an accident that had almost happened to her and didn't want to turn into the sort of woman who was afraid of men so she decides to go for a vacation. She gets an assignment to write a travel article about the fictional Caribbean island.

The toleration of violence in St. Antonia and St. Agathe is typical of many emerging nations. In these islands, economic problems combined with primitive social mores makes life extremely difficult mainly for women. There is seventy percent unemployment. The political scene on the island has no room for love and decency. Beating women is socially acceptable. Safety and law is nowhere. Many people live in tent camps and suffer from poverty and become the victim of corruption. Rennie comes to know all through Dr. Minnow. She finds her tragedy reflected in the tragedy of mute and innocent masses all over the world. She discovers that all human principles like democracy, liberation, and individual dignity are used as pretext to get "rid of people you don't like". [240]

Rennie finds the problem of violence against women exist in all societies. Physical violence is practiced more openly on such barbarous islands. Societal decay forces women to become victims. In an incident Rennie discovers that a campaign manager Marsdon beats and keeps his woman tied to tree for several hours and nobody comes to save her. Rennie comes in contact with Lora Lucas in Central American prison. She was a fellow prisoner. Lora tells Rennie the story of her life. When she was a child, her step father raped her. Lora says, "He hit me because he could get away with it and nobody could stop him". [114] Lora attacks her step father and escapes from home. She has started working in a boat and is shocked to know that all men around her expect to sleep with her and the condition is either to comply or to lose the job. In this patriarchal structure of society, her voice remains unheard. She has to experience social and sexual brutality every now and then, as she is helpless and powerless.

She is abused, repressed and physically deformed by the pattern of male expectation that society imposes upon her. The life stories of Lora Lucas completely shatter Rennie's over confidence in woman's liberation. Everyone wants to take advantage from her. Rennie witnesses how Lora very often obliges the prison guard for sex in return for the news of her lover. She is sexually assaulted, beaten, mutilated and ultimately killed by the policemen. The story of Lora shocked Rennie's feminist sensibility. In this male dominated society Lora's voice remains unheard and finally she becomes a quiet and victimized woman. She is attacked after a threat as she lashed out at the guards- the sight of the neglected dead body of Lora touches the heart of Rennie and she feels a sense of empathy with her. "Very carefully, she turns Lora over, her body is limp and thick, a dead weight. Dead end. She hauls Lora over to the driest corner of the room and sits with her pulling Lora's head and shoulders on to her lap". [290] The brutality done to Lora is the real bodily harm, which surpasses both in agony and shock than the partial surgery of breast cancer done to Rennie. She realizes that cancer has no significance and it is no more a minor accident of her life.

Rennie and Lora in their prison cells symbolize how women in all walks of life are victimized and oppressed by the hands of men. The brutal and heartless mutilation of Lora symbolically presents the limited gender specific role of women in society. In fact enforced alienation and identify crises come from the fact that women are trying to change place they have been given in society, i.e. taking care of house and children. Since Rennie has no children and a job of her own. Atwood has shown that single and professionally independent women are also not free of the patriarchal order. Bodily Harm is a dark character study of woman who feels shattered and discriminated under patriarchy.

\section{REFERENCES}

[1] Bodily Harm, Margaret Atwood McClelland and Stewart, 1981; Simon and Schuster, cape, 1980.

[2] The Voice of Margaret Atwood, Caedmon,1977.

[3] Atwood's reviews and critical articles appeared in Canadian Literature, Maclean's, Saturday Night and New York Times Book Review.

[4] Quotes and others are taken from Atwood's Bodily Harm. Vintage, 1996. 